\title{
Invisible gold in arsenian pyrite and arsenopyrite from a multistage Archaean gold deposit: Sunrise Dam, Eastern Goldfields Province, Western Australia
}

\author{
Y.-H. Sung • J. Brugger • C. L. Ciobanu • A. Pring • \\ W. Skinner $\cdot$ L. V. Danyushevsky $\cdot$ M. Nugus
}

Published online: 16 July 2009

(C) Springer-Verlag 2009

Erratum to: Miner Deposita

DOI 10.1007/s00126-009-0244-4

The original version of this article unfortunately contained a mistake. Leonid V. Danyushevsky was not listed among the authors. The corrected list of authors is given above.

The online version of the original article can be found at http://dx.doi. org/10.1007/s00126-009-0244-4

Y.-H. Sung $\cdot$ W. Skinner

Ian Wark Research Institute, University of South Australia,

Mawson Lakes, South Australia 5095, Australia

Y.-H. Sung $\cdot$ J. Brugger $\cdot$ C. L. Ciobanu $\cdot$ A. Pring

Division of Minerals. South Australian Museum,

Adelaide, South Australia 5000, Australia

J. Brugger $(\bowtie) \cdot$ C. L. Ciobanu $\cdot$ A. Pring

School of Earth and Environmental Sciences,

University of Adelaide,

Adelaide, South Australia 5000, Australia

e-mail: joel.brugger@adelaide.edu.au

L. V. Danyushevsky

CODES CoE and School of Earth Sciences,

University of Tasmania,

Hobart, TAS 7001, Australia

M. Nugus

Sunrise Dam Gold Mine, AngloGold Ashanti Australia Ltd,

Laverton, Western Australia 6001, Australia

Present Address:

Y.-H. Sung

Korea Resources Corporation,

79 Siheung daero, Dangjak-gu,

Seoul 156-706, South Korea 